\title{
Comparative quality analysis of kimchi products manufactured in Korea, Japan, and China
}

\author{
Hyejin Lee, Suyeon Jeong, Jaehwan Kim, SeungRan Yoo* \\ Research and Development Division Industrial Technology Research Group, World Institute of Kimchi, Gwangju 61755, Korea
}

\section{한국, 일본, 중국 김치의 품질 비교 분석}

\author{
이혜진 · 정수연 · 김재환·유승란* \\ 세계김치연구소 산업기술연구단
}

\begin{abstract}
The objective of the present study was to investigate differences in quality of kimchi products produced in Korea, Japan, and China. Kimchi products from kimchi-producing countries with high consumer consumption such as Japan and China along with local products from Korea, where exporting has not yet started, were collected. Product $\mathrm{pH}$, acidity, salinity, package pressure, gas production were assessed, and microbiological analyses and sensory evaluations were performed on kimchi products that were stored at either $4^{\circ} \mathrm{C}$ for $63 \mathrm{~d}$ or $15^{\circ} \mathrm{C}$ for $20 \mathrm{~d}$. The pH and acidity results showed that as Japanese and Chinese kimchi had higher pH and lower acidity than that of Korean kimchi, which was determined to be indicative of insufficient microbial fermentation following kimchi production. Japanese kimchi had different microbial properties than those of Korean kimchi, which is due to differences in their manufacturing processes. Overall preferences derived from sensory evaluations were: Korean kimchi $>$ Chinese kimchi>Japanese kimchi. The results of this study demonstrate the sensory superiority of Korean kimchi and may be useful when predicting consumers' acceptance level of Korean kimchi exported to other countries.
\end{abstract}

Key words : storage, sensory, kimchi, quality analysis

\section{서 론}

김치는 주재료인 채소를 소금으로 절인 후 각종 양념을 첨가하여 숙성시켜 먹는 우리나라 고유의 염장 발효식품으 로서 항암, 비만 방지, 동맥경화 억제, 항 균 등의 효능을 가진 것으로 알려졌다(1-6). 2001년 7월 김치에 대한 Codex 국제규격이 채택되고 2002년 김치가 한일 월드컵 공식 식 품으로 인정되면서, 우리나라의 김치 품질이 인정받게 되 었으며 김치 종주국으로서 위상을 높이게 되었다(7). 더불 어 2006년 미국 건강전문잡지 Health에서 김치가 세계 5대 건강식품으로 선정되면서 김치는 건강 발효 식품으로서

*Corresponding author. E-mail : sryoo@wikim.re.kr

Phone : 82-62-610-1738, Fax : 82-62-610-1850

Received 24 June 2016; Revised 10 October 2016; Accepted 25 November 2016.

Copyright (c) The Korean Society of Food Preservation. All rights reserved.
세계인의 관심을 더욱 받게 되었다(8). 그러나 최근 일본과 중국 김치 시장이 지속적으로 성장하고 있으며, 세계시장 에서의 시장 점유율도 높아지고 있는 실정이다.

우리나라는 일본, 베트남, 홍콩, 대만을 비롯한 세계 60여 국에 김치를 수출하고 있으며 그 중 일본은 수출 매출액의 $80 \%$ 이상을 차지하는 최대 수출국이다(9). 일본 김치 시장 은 2013년 기준, 730 억 엔으로 추정되며 한국산 김치의 수입 비중은 $10 \%$ 내외 수준으로 22 만 톤을 차지하고 있으 며 2003년부터 꾸준히 증가해 왔다(10). 일본의 경우 한국 에서 수입도 하고 있지만, 김치의 아삭한 질감과 단맛을 좋아하는 일본인의 입맛에 맞게 변형된 김치가 가장 많이 소비되고 있다 $(11,12)$. 일본에서는 거의 발효하지 않은 형 태의 김치를 생산하고 있으며, 일본김치는 아미노산, 유기 산, 소르비톨, 과일즙, 설탕 등의 당류를 첨가하여 발효되지 않고도 한국 김치처럼 숙성된 맛을 내는 특징이 있다. 그러 나 최근 소비자 입맛의 변화에 따라 한국식 김치 소비량이 늘고 있다(11-13). 또 다른 김치 소비국인 중국에서는, 김치 
시장이 지속적으로 성장하고 있으며 이에 따라 중국 내 김치 가공 공장 역시 급격하게 늘어나고 있다. 중국산 김치 의 특징은 젓갈 냄새가 약하고 한국산 김치보다 다소 매운 맛이 많이 나고 가격이 저렴해 세계시장에서 시장 점유율이 높아지고 있다(14). 중국산 김치의 한국으로의 수입은 확대 되고 있지만, 우리나라 김치는 중국 정부의 절임 채소류 기준에 적합하지 않아 중국 수출이 전혀 없었다(15). 그러나 2015년 2월, 중국이 비멸균 발효제품에 대해 대장균군 기준 을 적용하지 않는 절임 채소에 대한 식품안전국가표준 의견 수렴(안)을 발표함으로서 우리나라 김치의 중국 수출이 기 대되고 있다.

김치 원·부재료 및 제조방식에 따라 김치의 이화학적 특성, 관능적 특성 및 미생물 생육이 다르다는 연구 결과가 있다(16). 따라서, 일본이나 중국에 한국 김치를 수출하기 위해서는 김치 원·부재료 및 제조방식이 다른 한·중·일 삼 국의 김치 품질 특성에 관해 연구할 필요가 있으며, 수출국 에서 제조한 김치와 한국에서 제조한 김치와의 품질 차이를 분석하고 이를 토대로 더 나은 한국 김치를 생산하여야 할 것이다. Cho 등(17)은 최근 일본에서 유통되는 김치 상품 중에서 가장 점유율이 높은 5 가지 상품을 구입하여 국내에 서 유통되는 대표상품들과 그 화학적 및 미생물학적 특성을 비교 분석 하였다. Kim 등(16)은 한국산 배추와 일본산 배추 를 이용하여 한국식 및 일본식 김치를 제조한 뒤 품질 특성 을 비교 분석하였다. 그러나 한.중·일 삼국 현지에서 제조 된 김치에 관한 비교 연구는 진행된 바가 없는 실정이다. 한국 김치 의 품질을 더욱 발전시키고 수출을 촉진을 위하 여 활용할 수 있는 과학적 데이터를 확보하고자, 삼국 김치 의 저장 중 품질 변화를 비교 분석하였다.

\section{재료 및 방법}

\section{실험재료}

한국김치와 일본, 중국 김치와의 품질을 비교·분석하기 위해 비슷한 시기 $( \pm 2$ 일 $)$ 에 제조된 한국김치, 일본김치, 중 국김치를 구매하였다. 한국김치 품질 분석을 위해서는 광 주에서 제조되어 판매되고 있는 김치 5 종을 시료로 수집하 였다. 일본 현지에서 유통되고 있는 일본김치는 모두 200 $\mathrm{g}$ 이하의 소포장 형태였는데, 수집할 수 있었던 김치 6 종 중 품질 분석이 가능한 양을 가진 샘플 한 종을 시료로 선택하여 품질 분석을 하였다. 중국 김치 시료는 한국에서 유통되고 있는 중국김치 한 종을 선택하여 분석하였는데, 이는 방문한 중국김치 유통업체에서 모두 동일한 중국김치 를 유통시키고 있었던 것에 기인한다.

\section{시료 준비 및 저장방법}

7종의 김치 시료를 $500 \mathrm{~g}$ 씩 정량하여 포장 파우치에 넣고 sealing 한 후 김치의 발효 패턴을 분석하였다. 포장된 김치
는 $4^{\circ} \mathrm{C}$ (냉장고 온도)에서 8 주, $15^{\circ} \mathrm{C}$ (유통 및 수출시 가능 저장 온도)에서 20 일 동안 저장하였다.

\section{$\mathrm{pH}$ 및 적정산도}

$\mathrm{pH}$ 는 blender로 간 반죽상태의 시료에 $\mathrm{pH}$ electrode를 직접 넣어 측정하였다. 적정산도는 blender로 간 반죽상태 의 시료 약 $1 \mathrm{~g}$ 을 정확히 달아 희석 $(100 \mathrm{~mL})$ 하여 여과 (HYUNDAI Micro No.10, HYUNDAI Micro., Ltd., Seoul, Korea)한 후 여과액 $20 \mathrm{~mL}$ 에 $0.01 \mathrm{~N} \mathrm{NaOH}$ 용액으로 $\mathrm{pH}$ 가 8.3 이 될 때까지 적정하였다. 별도로 증류수에 대한 바탕시 험을 실시하여 다음 식에 따라 계산하였다.

$$
\text { 적정산도 }(\%)=\frac{(\mathrm{A}-\mathrm{B}) \times 0.0009 \times \mathbf{f} \times \mathrm{D}}{\mathrm{S}} \times 100
$$

$\mathrm{A}$ : 본 시험에 소비된 $0.01 \mathrm{~N} \mathrm{NaOH}$ 용액의 $\mathrm{mL}$ 수

$\mathrm{B}$ : 바탕시험에 소비된 $0.01 \mathrm{~N} \mathrm{NaOH}$ 용액의 $\mathrm{mL}$ 수

$0.0009: 0.01 \mathrm{~N} \mathrm{NaOH} 1 \mathrm{~mL}$ 에 상당하는 lactic acid(g)

f : $0.01 \mathrm{~N} \mathrm{NaOH}$ 용액의 역가

$\mathrm{D}$ : 희석배수

$\mathrm{S}$ : 시료채취량 $(\mathrm{g})$

\section{염 도}

Blender로 간 반죽상태의 시료 약 $1 \mathrm{~g}$ 을 정확히 달아 적당히 희석(약 100배)하여 여과(HYUNDAI Micro No. 10, HYUNDAI Micro., Ltd.)한 후 여과액 $10 \mathrm{~mL}$ 를 취하고, $2 \%$ potassium chromate $1 \mathrm{~mL}$ 를 넣어 $0.02 \mathrm{~N} \mathrm{AgNO}_{3}$ 용액으로 적정하였다. 별도로 증류수에 대한 바탕시험을 실시하여 다음 식에 따라 계산하였다.

$$
\text { 염도 }(\%)=\frac{(\mathrm{A}-\mathrm{B}) \times 0.00117 \times \mathbf{f} \times \mathbf{D}}{\mathrm{S}} \times 100
$$
$\mathrm{A}$ : 본 시험에 소비된 $0.02 \mathrm{~N} \mathrm{AgNO}_{3}$ 용액의 $\mathrm{mL}$ 수
$\mathrm{B}$ : 바탕시험에 소비된 $0.02 \mathrm{~N} \mathrm{AgNO}_{3}$ 용액의 $\mathrm{mL}$ 수
f : $0.02 \mathrm{~N} \mathrm{AgNO}_{3}$ 용액의 역가
$\mathrm{D}$ : 희석배수
$\mathrm{S}:$ 시료채취량 $(\mathrm{g})$

\section{미생물}

무균상태에서 시료 $10 \mathrm{~g}$ 을 취한 후 멸균된 $0.85 \%$ saline 용액으로 10배 희석하여 stomacher(bag mixer R400, Interscience, Saint Nom, France)로 균질화한 후 단계 희석하 여 실험을 실시하였다. 일반세균수의 경우 plate count agar(PCA Difco, Franklin Lakes, NJ, USA) 배지를 사용하여 단계별로 희석한 시료를 접종한 후 pouring culture method 로 $30^{\circ} \mathrm{C}$ 에서 48 시간 배양하여 계수하였다. 젖산균의 경우, 
MRS(Lacto-bacilli MRS Agar, Difco, New Jersey, USA) 배 지에 지시약 bromocresol purple $0.0025 \% \mathrm{w} / \mathrm{v}$ 을 첨가하여 제조한 $\mathrm{BCP}$ 배지를 사용하여 단계별로 희석한 시료를 접종 하고 pouring culture method로 $30^{\circ} \mathrm{C}$ 에서 48 시간 배양하였 다. 이때 노란색을 띄는 colony(유기산 생성균)를 계수하였 다. 또한, 김치 젖산균인 Lactobacillus spp.와 Leuconostoc spp.을 구별하기 위해 분별배지인 MRS(Lacto-bacilli MRS Agar, Difco)에 지시약 Bromophenol blue $0.002 \% \mathrm{w} / \mathrm{v}$ 을 첨 가하여 배지로 사용하였다. 제조한 BPB 배지에 단계별로 희석한 시료를 접종하고 pouring culture method로 $30^{\circ} \mathrm{C}$ 에서 48시간 배양하였다. Colony의 형태를 보고 Lactobacillus spp.와 Leuconostoc spp.를 구별하여 계수하였다. 계수한 균 의 집락 수는 colony forming unit(log $\mathrm{CFU} / \mathrm{g})$ 로 표시하였다.

\section{포장 내 가스조성, 압력}

김치 파우치의 포장에 따른 기체조성 분석은 Headspace Gas Analyser(GS3 Micro, illinois systech instruments, ULTRA TEC KOREA, Seoul, Korea)를 이용하여 포장 내 Headspace Gas를 측정하였으며 이 때 대기의 기체 조성은 $\mathrm{O}_{2} 20.9 \%, \mathrm{CO}_{2} 0.3 \%, \mathrm{~N}_{2} 78.8 \%$ 기준으로 측정하였다. 3 개의 시료로 반복 실험 하였으며, 1 개의 시료에서 2 번 측정하여 총 6회 반복 측정하였다. 포장 내 압력은 Headspace pressure gauge(UTK-P5000, ULTRA TEC KOREA)를 이용하여 측 정하였으며 이 때 대기압은 1.011 을 기준으로 하였다. 기체 조성과 마찬가지로 총 3 개의 시료로 반복 실험하였으며 각각의 시료에서 2 번 측정하여 총 6 회 반복 측정하였다.

\section{관능검사}

한국, 일본, 중국김치를 동일한 파우치에 넣어 포장한 후 $4^{\circ} \mathrm{C}$ 와 $15^{\circ} \mathrm{C}$ 에 저장하면서 관능검사를 진행하였다. 세계 김치연구소 내에서 반복된 랜덤화 완전 블록 계획에 따라 15 명의 패널요원을 선정하여 본 검사에 참여하도록 하였 다. 각 시료 검사 전에는 입안을 헹구도록 하였으며 물과 크래커를 제공하여 전 시료에 대한 관능 특성이 다음 시료 에 영향을 주지 않도록 하였다. 평가항목은 김치의 색, 신맛, 단맛, 매운맛, 이미, 아삭한 정도, 전체적인 기호도 총 7가지 항목을 실시하였다. 9점 항목 척도를 이용하였으며 전체적 인 기호도는 주관적으로(scale 1, 매우 싫다 scale 9, 매우 좋다)평가하였고, 나머지 항목들은 객관적 평가(scale 1, 매 우 약하다 scale 9, 매우 강하다)를 실시하였다.

\section{통계처리}

각 실험 결과는 3회 측정하여 그 평균값을 나타내었으며, 유의성 검증은 IBM SPSS Statistics(19, IBM Co., Armonk, $\mathrm{NY}, \mathrm{USA})$ 을 사용하여 Duncan의 다범위 검정(Duncan's multiple range test)을 통하여 $\mathrm{p}<0.05$ 수준으로 분석하였다.

\section{결과 및 고찰}

김치 저장 중 $\mathrm{pH}$, 산도 변화

$15^{\circ} \mathrm{C}$ 에서 김치의 발효 기간 중 $\mathrm{pH}$ 및 산도 변화는 Fig. 1 에 나타내었다. 한국, 일본, 중국김치에 대한 저장 실험 결과, 김치 종류와 관계없이 $\mathrm{pH}$ 는 전체적으로 감소하는 경향을 보였으며, 산도는 증가하는 경향을 보였다. 저장 20 일차의 $\mathrm{pH}$ 는 일본 김치는 평균 4.37 로 중국 김치 4.01 , 한국 김치 평균 $\mathrm{pH}$ 3.75에 비해 유의적으로 높게 나타났으 며 중국김치와 한국김치는 유사한 경향을 보였다. 앞선 선 행연구의 분석결과에서도 일본산 김치는 $\mathrm{pH}$ 가 4.4 5.0으로 본 연구 결과와 같이 국내산 김치보다 높은 경향을 보였다 $(9,19)$.
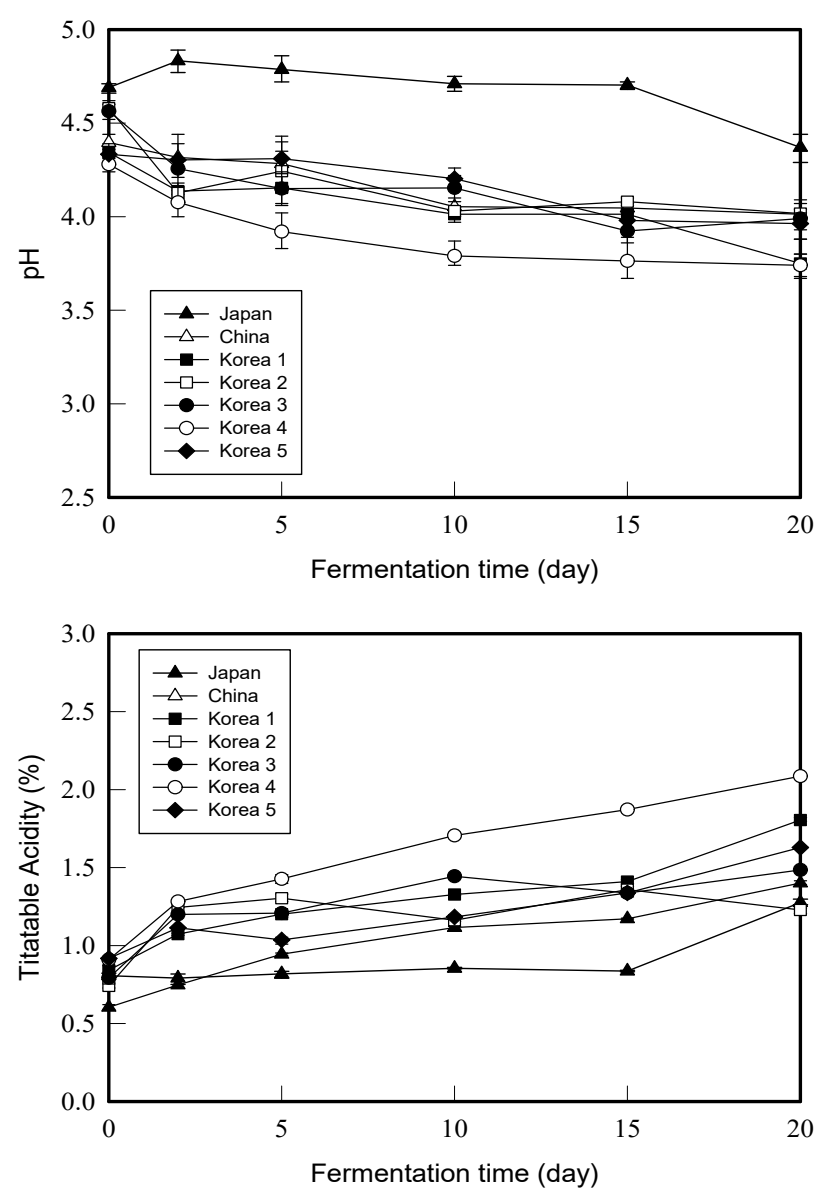

Fig. 1. $\mathrm{pH}$ values and titratable acidity changes of kimchi stored at $15^{\circ} \mathrm{C}$.

Values represent the mean $\pm \mathrm{SD}(\mathrm{n}=3)$.

$\mathrm{pH}$ 의 변화와는 반대로 저장 중 산도는 증가하였으며, 한국 김치와 비교하면 일본 김치와 중국 김치의 산도가 낮게 나타났다. 저장 중 젖산균에 의한 발효가 진행되면서 유기산이 생성되어 김치의 산도가 높아지게 된다. 또한, 이때 생성된 유기산은 $\mathrm{pH}$ 를 낮아지게 하며 김치 특유의 
감칠맛과 신맛에 영향을 주는 것으로 알려졌다(14). $4^{\circ} \mathrm{C}$ 에 서 저장된 한국, 일본, 중국김치의 $\mathrm{pH}$ 및 산도 변화는 $\mathrm{Fig}$. 2에 나타내었다. $\mathrm{pH}$ 의 경우 시간에 따른 변화는 미미했고, 산도의 경우 $15^{\circ} \mathrm{C}$ 에서 실험한 김치와 유사한 경향을 보였 다. $15^{\circ} \mathrm{C}$ 에서 저장한 김치보다 $4^{\circ} \mathrm{C}$ 에서 저장한 김치의 $\mathrm{pH}$ 와 산도 모두 변화 폭이 작게 나타났으며, 이를 통해 김치 저장 온도가 $\mathrm{pH}$ 및 산도에 영향을 주는 것을 확인하였다.

김치는 발효 과정에서 다양한 유산균이 관여하는데, 주 로 발효 초기에는 Leuconostoc, Weisella 등에 의해 이형발효 가 진행되고, 숙성 적기가 지나면 내산성이 강한 Lactobacillus 균종에 의한 동형발효가 진행되어 젖산 생성 량이 증가하는 것으로 알려져 있다(9). 김치의 숙성 중 생성 된 유기산 등은 김치 특유의 신선한 맛을 주게 되며 이에 따라 김치의 $\mathrm{pH}$ 는 감소하고 산도는 증가하게 된다. 이는, 유산균의 생육이나 김치의 발효 정도를 짐작할 수 있는 중요한 지표가 된다(19). 일본, 중국김치 제조 김치가 한국 김치보다 $\mathrm{pH}$ 는 높거나 비슷한 수준으로, 산도는 낮게 나온 것을 보아 미생물에 의한 유기산 생성이 한국김치보다 적은 것으로 보여진다.
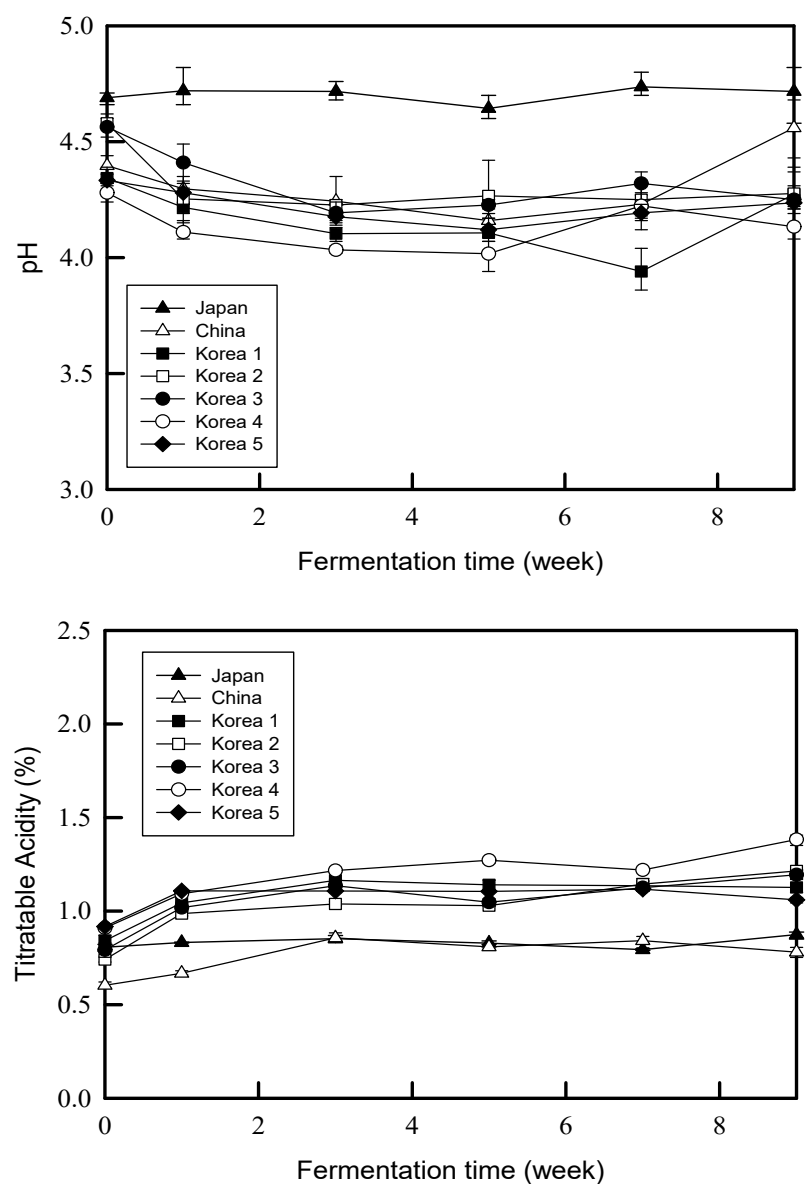

Fig. 2. $\mathrm{pH}$ values and titratable acidity changes of kimchi stored at $4^{\circ} \mathrm{C}$.

Values represent the mean $\pm \mathrm{SD}(\mathrm{n}=3)$.

\section{김치의 저장 중 염도 변화}

$15^{\circ} \mathrm{C}$ 에서 저장한 한국, 일본, 중국김치의 발효기간 중 염도 변화는 Fig. 3 에 나타내었다. 분석결과, 일본 김치의 염 농도가 2.93으로 중국 김치 및 한국 김치에 비해 높은 경향을 보였다. 또한, 중국 김치는 1.72 로 가장 낮은 염 농도 를 보였으며 한국 김치 5 종의 평균 염 농도는 2.00 을 나타내 었다. 이는 Cho 등(17)의 분석 결과에서도 일본 김치 5 종에 대한 염 농도 분석결과 1.88 2.98로 본 연구 결과와 같이 한국 김치보다 높은 염 농도 경향을 보였다. 김치에서 염 농도는 삼투압 작용으로 유해 미생물 생육을 억제할 뿐만 아니라, 내염성의 젖산균이 선택적으로 성장하도록 조절하 는 역할을 한다(20). 7 개의 김치 모두 시간에 따른 염도 변화는 미미하였다. 김치의 염도 변화가 비교적 적은 이유 는 발효 초기에 배추조직 내로 소금이 확산되어 탈수와 침투를 반복해 가기 때문이며, 발효 숙성이 진행됨에 따라 김치 국물과 배추 조직 사이에서 소금 농도의 평형이 이루 어졌기 때문이라고 판단된다 $(21,22) .4^{\circ} \mathrm{C}$ 에서 발효기간 중 김치의 염도 변화도 $15^{\circ} \mathrm{C}$ 에 저장한 김치의 염도 변화와 유사한 경향을 보였다.
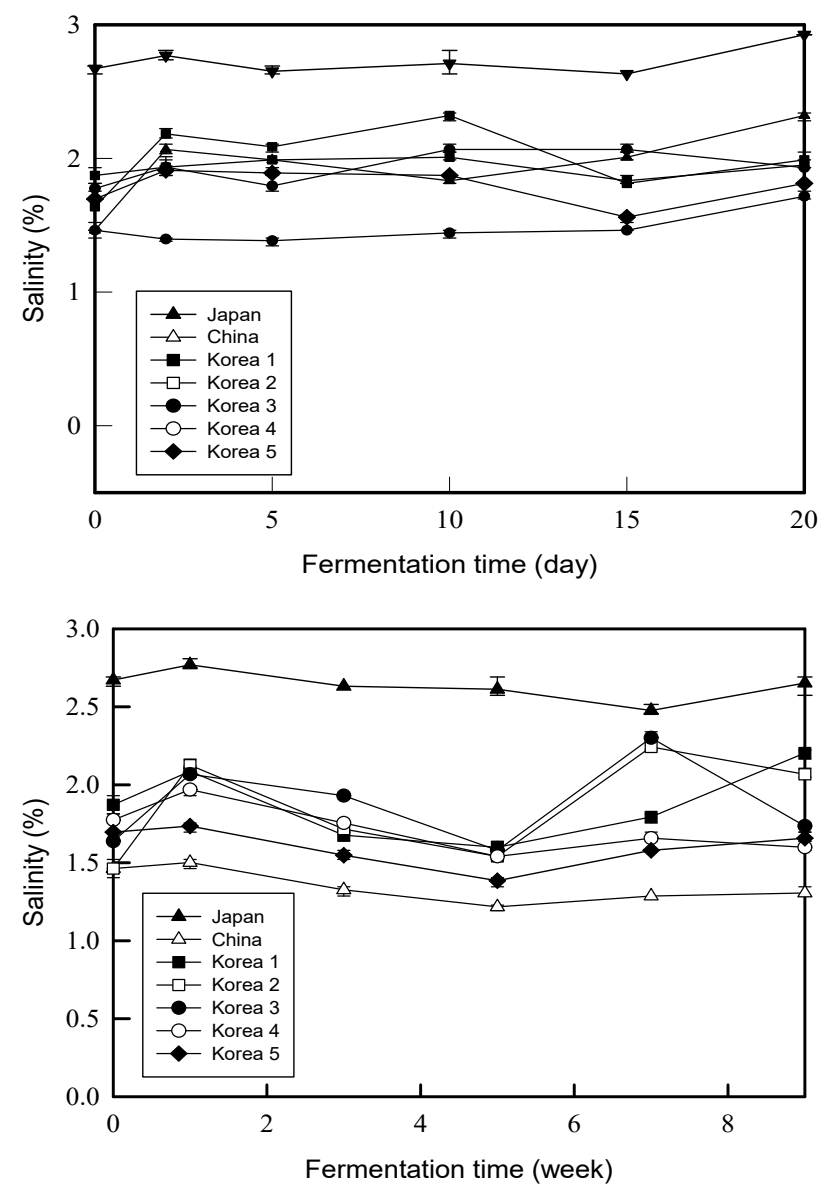

Fig. 3. Salinity changes of kimchi stored at $15^{\circ} \mathrm{C}$ and $4^{\circ} \mathrm{C}$. Values represent the mean $\pm \mathrm{SD}(\mathrm{n}=3)$. 


\section{김치의 미생물 측정 결과}

김치 발효 초기에는 이형발효형(heterofermentative)인 Leuconostoc mesenteroides과 Lactobacillus brevis가 많이 번 식하여 젖산, 에탄올, $\mathrm{CO}_{2}$ 등이 생성된다. 이들 발효산물에 의해 김치가 산성화되고 발효조건은 혐기상태로 되어 호기 성균의 성장이 억제된다. 발효 후기에는 동형발효형 (homofermentative)인 Lactobacillus plantarum이 많이 분포 되는데, 이 시기 중 Leuconostoc mesenteroides 수가 감소하 고 Lactobacillus plantarum의 수가 최대로 되는데 이 때를 김치가 완전히 시었다고 간주한다(23-26). $15^{\circ} \mathrm{C}$ 로 저장된 김치의 미생물학적 품질 특성 분석 결과는 Table 1 에 나타 내었다. 김치 수집 0 일차에서 일본 김치의 총균수는 3.51 $\log \mathrm{CFU} / \mathrm{g}$ 으로, 한국김치 $2=8.31 \log \mathrm{CFU} / \mathrm{g}$, 한국김치 4=8.02 $\log \mathrm{CFU} / \mathrm{g}$ 등과 비교하였을 때 현저하게 낮은 수치 를 보여주었다. 저장 동안 일본 김치에서 측정된 Total aerobic bacteria, Lactic acid bacteria, Lactobacillus spp., Leuconostoc spp. 의 수치가 모두 낮은 것으로 보여 일본 김치는 미생물에 의한 발효가 충분히 진행되지 않은 것으로 판단된다. 일본 현지에서 생산하는 김치는 유산균에 의해
발효되는 한국식 김치와 달리 소르비톨, 과일즙, 설탕 등을 첨가하여 제조되는 김치로 한국의 김치 제조법과는 차이가 있어 미생물의 특성도 다르게 나타났다고 보인다. 일본 김 치의 경우 대수기 없이 저장 기간 동안 꾸준히 미생물이 증가하였다. 일본 김치를 제외한 나머지 처리구에서는 저 장 2 5일차에 대수기에 접어들어 총균수, 총 젖산균이 가장 높은 수치를 보였다. 대수기의 총 젖산균 결과를 보면, 중국 김치는 $8.52 \log \mathrm{CFU} / \mathrm{g}$ 를 나타내었고, 한국 김치는 7.89 8.57 $\log \mathrm{CFU} / \mathrm{g}$ 의 수치를 나타내어 중국 김치와 한국 김치 간의 수치 차이는 거의 없었다 $(\mathrm{p}>0.05)$. 한국 김치 5 종 의 미생물 특성은 비슷한 수치로 나타났다. 5 개 처리구 모두 발효 초기 중기까지는 김치의 젖산균 중 Lactobacillus spp. 의 수치가 높았고, 발효 중기 말기에는 Leuconostoc spp. 종 의 수치가 더 높게 나타났다. 한국김치 2 의 경우 최대 Leuconostoc spp.의 수치가 $8.85 \log \mathrm{CFU} / \mathrm{g}$ 로 다른 처리구 보다 높은 결과를 나타냈다. 김치의 상쾌한 맛을 주는 탄산 미는 보통 $\mathrm{CO}_{2}$ 및 탄산에 의한 것이며, 김치 발효 중 $\mathrm{CO}_{2}$ 생성량은 이형젓산발효균인 Leuconostoc mesenteroides균 이 관여하게 된다. 한국김치 2 의 관능평가 결과, 전체적인

Table 1. Microbial population in the kimchi stored at $15^{\circ} \mathrm{C}$

(unit: $\log \mathrm{CFU} / \mathrm{g}$ )

\begin{tabular}{|c|c|c|c|c|c|c|c|c|}
\hline & Period (day) & Japan & China & Korea 1 & Korea 2 & Korea 3 & Korea 4 & Korea 5 \\
\hline \multirow{5}{*}{ Total aerobic bacteria } & 0 & $3.51 \pm 0.01^{1 \mathrm{~F} 2 \mathrm{e}) 33}$ & $7.62 \pm 0.01^{\mathrm{Cd}}$ & $7.45 \pm 0.13^{\mathrm{Dc}}$ & $8.31 \pm 0.09^{\mathrm{Ad}}$ & $6.99 \pm 0.12^{\mathrm{Ee}}$ & $8.02 \pm 0.01^{\mathrm{Bd}}$ & $7.57 \pm 0.13^{\mathrm{Cb}}$ \\
\hline & 2 & $6.51 \pm 0.03^{\mathrm{Ga}}$ & $7.95 \pm 0.01^{\mathrm{Fc}}$ & $9.34 \pm 0.03^{\mathrm{Aa}}$ & $8.90 \pm 0.02^{\mathrm{Ba}}$ & $8.36 \pm 0.02^{\mathrm{Ea}}$ & $8.58 \pm 0.01^{\mathrm{Da}}$ & $8.76 \pm 0.01^{\mathrm{Ca}}$ \\
\hline & 5 & $5.70 \pm 0.00^{\mathrm{Dd}}$ & $8.21 \pm 0.07^{\mathrm{BCa}}$ & $7.89 \pm 0.03^{\mathrm{cb}}$ & $8.62 \pm 0.00^{\mathrm{Ab}}$ & $8.13 \pm 0.04^{\mathrm{BCc}}$ & $8.33 \pm 0.03^{\mathrm{ABC}}$ & $8.41 \pm 0.74^{\mathrm{ABa}}$ \\
\hline & 10 & $5.58 \pm 0.05^{\mathrm{Gc}}$ & $7.41 \pm 0.01^{\mathrm{Fe}}$ & $7.86 \pm 0.12^{\mathrm{cb}}$ & $8.41 \pm 0.04^{\mathrm{Ac}}$ & $8.25 \pm 0.04^{\mathrm{Fb}}$ & $8.32 \pm 0.01^{\mathrm{Bc}}$ & $7.69 \pm 0.02^{\mathrm{Eb}}$ \\
\hline & 20 & $6.29 \pm 0.03^{\mathrm{Fb}}$ & $8.15 \pm 0.06^{\mathrm{Bb}}$ & $7.33 \pm 0.18^{\mathrm{Ec}}$ & $8.07 \pm 0.07^{\mathrm{Be}}$ & $7.73 \pm 0.00^{\mathrm{Dd}}$ & $8.46 \pm 0.12^{\mathrm{Ab}}$ & $7.90 \pm 0.03^{\mathrm{Cb}}$ \\
\hline \multirow{5}{*}{ Lactic acid bacteria } & 0 & $3.19 \pm 0.06^{\mathrm{Fe}}$ & $7.55 \pm 0.08^{\mathrm{Ec}}$ & $7.74 \pm 0.04^{\mathrm{De}}$ & $8.54 \pm 0.01^{\mathrm{Ab}}$ & $7.56 \pm 0.00^{\mathrm{Ec}}$ & $8.17 \pm 0.02^{\mathrm{Cd}}$ & $8.35 \pm 0.01^{\mathrm{Ba}}$ \\
\hline & 2 & $5.11 \pm 0.01^{\mathrm{Gc}}$ & $7.96 \pm 0.02^{\mathrm{Eb}}$ & $8.20 \pm 0.04^{\mathrm{Db}}$ & $8.80 \pm 0.12^{\mathrm{Aa}}$ & $8.28 \pm 0.01^{\mathrm{Cab}}$ & $8.41 \pm 0.01^{\mathrm{Ba}}$ & $7.85 \pm 0.01^{\mathrm{Fe}}$ \\
\hline & 5 & $5.74 \pm 0.06^{\mathrm{Ed}}$ & $8.52 \pm 0.00^{\mathrm{Aa}}$ & $8.15 \pm 0.02^{\mathrm{Dc}}$ & $8.57 \pm 0.03^{\mathrm{Ab}}$ & $8.14 \pm 0.03^{\mathrm{Db}}$ & $8.36 \pm .008^{B b}$ & $8.23 \pm 0.06^{\mathrm{Cc}}$ \\
\hline & 10 & $5.32 \pm 0.09^{\mathrm{Eb}}$ & $7.98 \pm 0.09^{\mathrm{Bb}}$ & $7.78 \pm 0.00^{\mathrm{Cd}}$ & $7.15 \pm 0.06^{\mathrm{Dd}}$ & $8.35 \pm 0.24^{\mathrm{Aa}}$ & $8.24 \pm 0.02^{\mathrm{Ac}}$ & $8.05 \pm 0.02^{\mathrm{Bd}}$ \\
\hline & 20 & $6.27 \pm 0.01^{\mathrm{Fa}}$ & $8.53 \pm 0.00^{\mathrm{Aa}}$ & $8.56 \pm 0.02^{\mathrm{Aa}}$ & $8.21 \pm 0.11^{\mathrm{Dc}}$ & $8.14 \pm 0.03^{\mathrm{Eb}}$ & $8.43 \pm 0.00^{\mathrm{Ba}}$ & $8.28 \pm 0.03^{\mathrm{Cb}}$ \\
\hline \multirow{5}{*}{ Lactobacillus spp. } & 0 & $3.36 \pm 0.03^{\mathrm{Fc}}$ & $7.07 \pm 0.03^{\mathrm{Cc}}$ & $6.65 \pm 0.07^{\mathrm{De}}$ & $7.93 \pm 0.04^{\mathrm{Ac}}$ & $6.30 \pm 0.00^{\mathrm{Ec}}$ & $6.60 \pm 0.02^{\mathrm{Dd}}$ & $7.79 \pm 0.11^{\mathrm{Bb}}$ \\
\hline & 2 & $5.64 \pm 0.01^{\mathrm{Ea}}$ & $7.44 \pm 0.01^{\mathrm{Cd}}$ & $7.66 \pm 0.01^{\mathrm{Bd}}$ & $8.23 \pm 0.07^{\mathrm{Ab}}$ & $7.15 \pm 0.21^{\mathrm{Db}}$ & $7.39 \pm 0.12^{\mathrm{Cc}}$ & $7.39 \pm 0.12^{\mathrm{Cc}}$ \\
\hline & 5 & $5.54 \pm 0.09^{\mathrm{Ec}}$ & $8.07 \pm 0.15^{\mathrm{Bc}}$ & $8.56 \pm 0.10^{\mathrm{Cb}}$ & $8.56 \pm 0.10^{\mathrm{Aa}}$ & $8.06 \pm 0.01^{\mathrm{Ba}}$ & $6.15 \pm 0.11^{\mathrm{Be}}$ & $8.09 \pm 0.05^{\mathrm{Ba}}$ \\
\hline & 10 & $4.39 \pm 0.55^{\mathrm{Cb}}$ & $8.20 \pm 0.04^{\mathrm{Ab}}$ & $7.84 \pm 0.08^{\mathrm{Bc}}$ & $8.18 \pm 0.04^{\mathrm{Ab}}$ & $8.19 \pm 0.02^{\mathrm{Aa}}$ & $8.33 \pm 0.04^{\mathrm{Aa}}$ & $8.10 \pm 0.02^{\mathrm{ABa}}$ \\
\hline & 20 & $4.39 \pm 0.12^{\mathrm{Fb}}$ & $8.56 \pm 0.04^{\mathrm{Aa}}$ & $8.22 \pm 0.06^{\mathrm{Ba}}$ & $7.81 \pm 0.05^{\mathrm{Ed}}$ & $8.11 \pm 0.05^{\mathrm{Ca}}$ & $8.20 \pm 0.00^{\mathrm{BCb}}$ & $8.02 \pm 0.09^{\mathrm{Da}}$ \\
\hline \multirow{5}{*}{ Leuconostoc spp. } & 0 & $3.48 \pm 0.02^{\mathrm{Gd}}$ & $7.20 \pm 0.05^{\mathrm{Ec}}$ & $7.08 \pm 0.01^{\mathrm{Fd}}$ & $8.32 \pm 0.03^{\mathrm{Ab}}$ & $7.31 \pm 0.08^{D c}$ & $7.92 \pm 0.04^{\mathrm{Ca}}$ & $8.19 \pm 0.05^{\mathrm{Bb}}$ \\
\hline & 2 & $6.04 \pm 0.01^{\mathrm{Eb}}$ & $7.83 \pm 0.02^{\mathrm{Db}}$ & $8.08 \pm 0.01^{\mathrm{Ca}}$ & $8.85 \pm 0.04^{\mathrm{Aa}}$ & $8.11 \pm 0.10^{\mathrm{Ca}}$ & $8.13 \pm 0.07^{\mathrm{Ca}}$ & $8.56 \pm 0.03^{\mathrm{Ba}}$ \\
\hline & 5 & $5.15 \pm 0.21^{\mathrm{Fe}}$ & $8.11 \pm 0.01^{\mathrm{Aa}}$ & $7.84 \pm 0.09^{\mathrm{Dcd}}$ & $7.84 \pm 0.09^{\mathrm{Bc}}$ & $7.67 \pm 0.06^{\mathrm{Cb}}$ & $5.98 \pm 0.03^{\mathrm{Ec}}$ & $7.76 \pm 0.07^{\mathrm{BCc}}$ \\
\hline & 10 & $5.27 \pm 0.02^{\mathrm{Dc}}$ & $7.77 \pm 0.10^{\mathrm{Ab}}$ & $7.28 \pm 0.00^{\mathrm{Bc}}$ & $7.45 \pm 0.21^{\mathrm{Bd}}$ & $7.00 \pm 0.00^{\mathrm{Cd}}$ & $7.30 \pm 0.43^{\mathrm{Bb}}$ & $7.50 \pm 0.28^{\mathrm{Bd}}$ \\
\hline & 20 & $6.28 \pm 0.00^{\mathrm{Ea}}$ & $8.18 \pm 0.10^{\mathrm{Aa}}$ & $7.45 \pm 0.21^{\mathrm{Db}}$ & $7.80 \pm 0.14^{\mathrm{Cc}}$ & $7.75 \pm 0.21^{\mathrm{Cb}}$ & $8.02 \pm 0.03^{\mathrm{ABa}}$ & $7.90 \pm 0.08^{\mathrm{BC}}$ \\
\hline
\end{tabular}

\footnotetext{
${ }^{1)}$ All values are mean $\pm \mathrm{SD}(\mathrm{n}=3)$.
}

${ }^{2) A-G}$ Means sharing different letters in the same row are significantly different by Duncan's multiple range test $(\mathrm{p}<0.05)$.

${ }^{3) \text { ate }}$ Means sharing different letters in the same column are significantly different by Duncan's multiple range test $(p<0.05)$. 
기호도가 가장 높게 나타났고, 이는 높은 Leuconostoc spp. 의 수치가김치의 풍미와 탄산미에 영향을 주기 때문으로 보여진다(27). Table 2 은 $4^{\circ} \mathrm{C}$ 로 저장된 김치의 미생물학적 품질 특성 분석 결과를 보여주고 있다. 저장 기간 동안의 일본 김치의 총균수는 저장초기 $3.51 \log \mathrm{CFU} / \mathrm{g}$, 중기 6.31 $\log \mathrm{CFU} / \mathrm{g}$, 말기 $4.88 \log \mathrm{CFU} / \mathrm{g}$ 로 한국, 중국김치보다 낮은 수치를 나타냈었다. 중국 김치와 한국 김치 5 종의 총균수는 저장 초기 6.99 8.31 $\log \mathrm{CFU} / \mathrm{g}$, 중기 6.48 7.68 $\log \mathrm{CFU} / \mathrm{g}$, 말기 4.78 6.92 $\log \mathrm{CFU} / \mathrm{g}$ 로 저장 초기, 중기에는 한국/중국 김치 5 종의 총균수와 비슷한 수치를 나타내었지만(p>0.05), 저장 말기의 한국, 중국의 총균수는 유의적인 차이가 있었 다 $(\mathrm{p}<0.05) .4{ }^{\circ} \mathrm{C}$ 로 저장된 중국 김치와 한국 김치 $1 \sim 5$ 의 대수기는 저장 7일차에 나타났고, 일본 김치는 저장 7 21일 사이에 나타났다. 대수기의 총 젖산균 결과, 일본김치의 경우 $6.32 \log \mathrm{CFU} / \mathrm{g}$ 로 가장 낮은 수치를 보여주었고, 중국,
한국 김치 $1 \sim 5$ 는 7.88 8.54 log $\mathrm{CFU} / \mathrm{g}$ 로 $15^{\circ} \mathrm{C}$ 에 저장된 김 치 젖산균과 비슷한 수치를 나타냈다. $4^{\circ} \mathrm{C}$ 에 저장한 김치의 젖산균의 출현빈도를 보면 모든 처리구에서 발효 초기, 중 기에는 Leuconostoc mesenteroides 등이 중기, 말기에는 Lactobacillus 계통이 지배적인 것들임을 알 수 있다. 온도에 따라 김치 젖산균 속의 출현빈도 역시 다르게 나타난다고 알려졌는데(27), 이 연구에서 역시 $4^{\circ} \mathrm{C}$ 와 $15^{\circ} \mathrm{C}$ 로 저장된 김치에서 다른 양상을 보여주었다. $15^{\circ} \mathrm{C}$ 로 저장된 한국 김 치 5 종의 대수기 총 젖산균의 수치는 8.14 8.57 $\log \mathrm{CFU} / \mathrm{g}$ 으 로 나타났지만, $4^{\circ} \mathrm{C}$ 로 저장된 한국 김치 5 종의 대수기 총 젖산균의 수치는 7.88 8.37 $\log \mathrm{CFU} / \mathrm{g}$ 로 $15^{\circ} \mathrm{C}$ 에 저장된 김 치 젖산균 수치가 더 높은 것을 알 수 있다. $15^{\circ} \mathrm{C}$ 로 저장된 김치와 마찬가지로 $4^{\circ} \mathrm{C}$ 에 저장된 한국, 중국 김치의 미생물 학적 특성 차이는 크지 않았다. $15^{\circ} \mathrm{C}$ 에서는 한국 김치 5 종이 높은 값의 Lactobacillus spp.를 나타내었으나, $4^{\circ} \mathrm{C}$ 에서는

Table 2. Microbial population in kimchi stored at $4^{\circ} \mathrm{C}$

(unit: $\log \mathrm{CFU} / \mathrm{g}$ )

\begin{tabular}{|c|c|c|c|c|c|c|c|c|}
\hline & Period (day) & Japan & China & Korea 1 & Korea 2 & Korea 3 & Korea 4 & Korea 5 \\
\hline \multirow{6}{*}{$\begin{array}{l}\text { Total aerobic } \\
\text { bacteria }\end{array}$} & 0 & $3.51 \pm 0.01^{1 / F 2 f(3)}$ & $7.62 \pm 0.01^{\mathrm{Cb}}$ & $7.45 \pm 0.13^{\mathrm{Db}}$ & $8.31 \pm 0.09^{\mathrm{Aa}}$ & $6.99 \pm 0.12^{\mathrm{Ed}}$ & $8.02 \pm 0.01^{\mathrm{Bb}}$ & $7.57 \pm 0.13^{\mathrm{cb}}$ \\
\hline & 7 & $5.54 \pm 0.04^{\mathrm{Ed}}$ & $7.70 \pm 0.07^{\mathrm{Ca}}$ & $8.15 \pm 0.03^{\mathrm{Ba}}$ & $7.52 \pm 0.04^{\mathrm{Dc}}$ & $8.22 \pm 0.05^{\mathrm{Aa}}$ & $8.19 \pm 0.05^{\mathrm{ABa}}$ & $8.14 \pm 0.01^{\mathrm{Ba}}$ \\
\hline & 21 & $6.31 \pm 0.03^{\mathrm{Fa}}$ & $7.52 \pm 0.06^{\mathrm{Bc}}$ & $6.48 \pm 0.02^{\mathrm{Ed}}$ & $7.08 \pm 0.03^{\mathrm{Cd}}$ & $7.68 \pm 0.05^{\mathrm{Abc}}$ & $6.18 \pm 0.04^{\mathrm{Gc}}$ & $6.94 \pm 0.05^{\mathrm{Dc}}$ \\
\hline & 35 & $6.00 \pm 0.07^{\mathrm{Gb}}$ & $6.48 \pm 0.01^{\mathrm{Ed}}$ & $6.33 \pm 0.01^{\mathrm{Fe}}$ & $7.94 \pm 0.01^{\mathrm{Ab}}$ & $7.75 \pm 0.01^{\mathrm{Bb}}$ & $6.59 \pm 0.00^{\mathrm{Dd}}$ & $6.70 \pm 0.02^{\mathrm{C}^{\mathrm{C}}}$ \\
\hline & 49 & $5.67 \pm 0.01^{\mathrm{Fc}}$ & $6.20 \pm 0.02^{\mathrm{Ee}}$ & $6.48 \pm 0.04^{\mathrm{Dc}}$ & $7.49 \pm 0.00^{\mathrm{Bc}}$ & $7.60 \pm 0.09^{\mathrm{Ac}}$ & $6.16 \pm 0.02^{\mathrm{Fe}}$ & $6.98 \pm 0.01^{\mathrm{Ce}}$ \\
\hline & 63 & $4.88 \pm 0.00^{\mathrm{CDe}}$ & $4.78 \pm 0.05^{\mathrm{Df}}$ & $5.13 \pm 0.02^{\mathrm{Cf}}$ & $6.92 \pm 0.67^{\mathrm{Ad}}$ & $5.96 \pm 0.00^{\mathrm{Be}}$ & $6.04 \pm 0.00^{\mathrm{Ba}}$ & $5.20 \pm 0.04^{\mathrm{Ce}}$ \\
\hline \multirow{6}{*}{$\begin{array}{c}\text { Lactic acid } \\
\text { bacteria }\end{array}$} & 0 & $3.19 \pm 0.06^{\mathrm{Ff}}$ & $7.55 \pm 0.08^{\mathrm{Eb}}$ & $7.74 \pm 0.04^{\mathrm{Db}}$ & $8.54 \pm 0.01^{\mathrm{Aa}}$ & $7.56 \pm 0.00^{\mathrm{Ec}}$ & $8.17 \pm 0.02^{\mathrm{Ca}}$ & $8.35 \pm 0.01^{\mathrm{Ba}}$ \\
\hline & 7 & $3.29 \pm 0.05^{\mathrm{Ee}}$ & $7.87 \pm 0.07^{\mathrm{Da}}$ & $8.37 \pm 0.00^{\mathrm{Aa}}$ & $7.88 \pm 0.01^{\mathrm{Db}}$ & $7.98 \pm 0.01^{\mathrm{Ca}}$ & $8.17 \pm 0.00^{\mathrm{Ba}}$ & $8.16 \pm 0.05^{\mathrm{Bb}}$ \\
\hline & 21 & $6.32 \pm 0.09^{\mathrm{Ea}}$ & $7.37 \pm 0.13^{\mathrm{Bc}}$ & $6.91 \pm 0.01^{\mathrm{Cc}}$ & $6.89 \pm 0.00^{\mathrm{Ce}}$ & $7.56 \pm 0.03^{\mathrm{Ac}}$ & $6.18 \pm 0.04^{\mathrm{Ca}}$ & $6.44 \pm 0.07^{\mathrm{Dd}}$ \\
\hline & 35 & $6.02 \pm 0.04^{\mathrm{Gb}}$ & $6.67 \pm 0.05^{\mathrm{Cd}}$ & $6.15 \pm 0.04^{\mathrm{Ee}}$ & $7.80 \pm 0.00^{\mathrm{Ac}}$ & $7.65 \pm 0.01^{\mathrm{Bb}}$ & $6.08 \pm 0.04^{\mathrm{Bb}}$ & $6.61 \pm 0.04^{\mathrm{DC}}$ \\
\hline & 49 & $5.63 \pm 0.03^{\mathrm{Gc}}$ & $6.50 \pm 0.07^{\mathrm{De}}$ & $6.69 \pm 0.11^{\mathrm{Cd}}$ & $7.42 \pm 0.01^{\mathrm{Ad}}$ & $6.84 \pm 0.10^{\mathrm{Bd}}$ & $6.06 \pm 0.01^{\mathrm{Fb}}$ & $6.30 \pm 0.03^{\mathrm{Ee}}$ \\
\hline & 63 & $4.78 \pm 0.05^{\mathrm{Ed}}$ & $4.19 \pm 0.06^{\mathrm{Ff}}$ & $4.93 \pm 0.04^{\mathrm{Df}}$ & $5.68 \pm 0.01^{\mathrm{Bf}}$ & $5.94 \pm 0.01^{\mathrm{Ae}}$ & $5.98 \pm 0.01^{\mathrm{Fc}}$ & $5.13 \pm 0.02^{\mathrm{Cf}}$ \\
\hline \multirow{6}{*}{ Lactobacillus spp. } & 0 & $3.36 \pm 0.03^{\mathrm{Fd}}$ & $7.07 \pm 0.03^{\mathrm{Cb}}$ & $6.65 \pm 0.07^{\mathrm{Dc}}$ & $7.93 \pm 0.04^{\mathrm{Aa}}$ & $6.30 \pm 0.00^{\mathrm{Ee}}$ & $6.60 \pm 0.02^{\mathrm{Ad}}$ & $7.79 \pm 0.11^{\mathrm{Ba}}$ \\
\hline & 7 & $3.20 \pm 0.04^{\mathrm{Ee}}$ & $6.99 \pm 0.12^{\mathrm{Bc}}$ & $8.12 \pm 0.03^{\mathrm{Aa}}$ & $7.87 \pm 0.02^{\mathrm{CDd}}$ & $7.98 \pm 0.01^{\mathrm{De}}$ & $8.17 \pm 0.00^{\mathrm{Db}}$ & $8.16 \pm 0.05^{\mathrm{BCD}}$ \\
\hline & 21 & $5.65 \pm 0.03^{\mathrm{Eab}}$ & $8.35 \pm 0.01^{\mathrm{Aa}}$ & $6.34 \pm 0.02^{\mathrm{Dd}}$ & $6.28 \pm 0.14^{\mathrm{De}}$ & $7.40 \pm 0.06^{\mathrm{Bb}}$ & $5.39 \pm 0.12^{\mathrm{BCa}}$ & $7.18 \pm 0.04^{\mathrm{cb}}$ \\
\hline & 35 & $5.62 \pm 0.01^{\mathrm{Eb}}$ & $6.65 \pm 0.03^{\mathrm{Bd}}$ & $6.09 \pm 0.07^{\mathrm{De}}$ & $7.74 \pm 0.01^{\mathrm{Ab}}$ & $7.76 \pm 0.01^{\mathrm{Aa}}$ & $6.05 \pm 0.04^{\mathrm{Ff}}$ & $6.50 \pm 0.05^{\mathrm{Cd}}$ \\
\hline & 49 & $5.66 \pm 0.02^{\mathrm{Ga}}$ & $6.38 \pm 0.03^{\mathrm{De}}$ & $6.88 \pm 0.01^{\mathrm{Bb}}$ & $7.29 \pm 0.02^{\mathrm{Ac}}$ & $6.71 \pm 0.11^{\mathrm{Cc}}$ & $5.91 \pm 0.01^{\mathrm{Dc}}$ & $6.25 \pm 0.01^{\mathrm{Ee}}$ \\
\hline & 63 & $4.48 \pm 0.02^{\mathrm{Fc}}$ & $4.10 \pm 0.02^{\mathrm{Gf}}$ & $5.20 \pm 0.04^{\mathrm{Df}}$ & $5.77 \pm 0.04^{\mathrm{Bf}}$ & $5.92 \pm 0.01^{\mathrm{Af}}$ & $5.70 \pm 0.01^{\mathrm{Fd}}$ & $5.02 \pm 0.03^{\mathrm{EF}}$ \\
\hline \multirow{6}{*}{ Leuconostoc spp. } & 0 & $3.48 \pm 0.02^{\mathrm{Gd}}$ & $7.20 \pm 0.05^{\mathrm{Ec}}$ & $7.08 \pm 0.01^{\mathrm{Fb}}$ & $8.32 \pm 0.03^{\mathrm{Aa}}$ & $7.31 \pm 0.08^{\mathrm{Dc}}$ & $7.92 \pm 0.04^{\mathrm{Ce}}$ & $8.19 \pm 0.05^{\mathrm{Ba}}$ \\
\hline & 7 & $3.37 \pm 0.07^{\mathrm{Ed}}$ & $7.84 \pm 0.01^{\mathrm{Db}}$ & $8.34 \pm 0.04^{\mathrm{Aa}}$ & $7.84 \pm 0.04^{\mathrm{Db}}$ & $8.19 \pm 0.09^{\mathrm{Ca}}$ & $8.26 \pm 0.01^{\mathrm{cb}}$ & $8.17 \pm 0.03^{\mathrm{Ca}}$ \\
\hline & 21 & $6.30 \pm 0.01^{\mathrm{Da}}$ & $8.42 \pm 0.82^{\mathrm{Aa}}$ & $6.87 \pm 0.00^{\mathrm{Cc}}$ & $6.79 \pm 0.00^{\mathrm{Ce}}$ & $7.45 \pm 0.03^{\mathrm{Bb}}$ & $6.30 \pm 0.17^{\mathrm{Ba}}$ & $7.13 \pm 0.02^{\mathrm{BCb}}$ \\
\hline & 35 & $6.02 \pm 0.0^{\mathrm{Eb}}$ & $6.63 \pm 0.02^{\mathrm{Bd}}$ & $6.10 \pm 0.02^{\mathrm{Fd}}$ & $7.60 \pm 0.03^{\mathrm{Ac}}$ & $6.15 \pm 0.21^{\mathrm{Dd}}$ & $5.74 \pm 0.06^{\mathrm{Dc}}$ & $6.39 \pm 0.12^{\mathrm{Cc}}$ \\
\hline & 49 & $5.62 \pm 0.01^{\mathrm{Ce}}$ & $5.30 \pm 0.43^{\mathrm{De}}$ & $5.54 \pm 0.09^{\mathrm{Ce}}$ & $7.13 \pm 0.07^{\mathrm{Ad}}$ & $5.95 \pm 0.00^{\mathrm{Be}}$ & $5.23 \pm 0.04^{\mathrm{De}}$ & $6.11 \pm 0.10^{\mathrm{Bd}}$ \\
\hline & 63 & $3.24 \pm 0.34^{\mathrm{Ee}}$ & $3.84 \pm 0.09^{\mathrm{Df}}$ & $4.15 \pm 0.21^{\mathrm{Cf}}$ & $4.65 \pm 0.07^{\mathrm{Bf}}$ & $5.08 \pm 0.00^{\mathrm{Af}}$ & $4.65 \pm 0.07^{\mathrm{Bf}}$ & $4.60 \pm 0.00^{\mathrm{Be}}$ \\
\hline
\end{tabular}

\footnotetext{
${ }^{1)}$ All values are mean $\pm \mathrm{SD}(\mathrm{n}=3)$.

${ }^{2) A-G}$ Means sharing different letters in the same row are significantly different by Duncan's multiple range test $(p<0.05)$.

${ }^{3) a-f}$ Means sharing different letters in the same column are significantly different by Duncan's multiple range test $(p<0.05)$.
} 
중국 김치가 최대값 $8.35 \log \mathrm{CFU} / \mathrm{g}$ 로 가장 높은 값을 나타 내었다.

\section{한국, 일본, 중국 제조 김치의 파우치 내부의 압력 및 가 스조성}

$4{ }^{\circ} \mathrm{C}$ 에 저장된 한국, 일본, 중국김치 파우치 내부의 압력 변화 결과는 Table 3 와 같다. 파우치 내부의 압력 측정은 저장 0 일차와 63 일차에 측정하였다. 측정 결과, 모든 처리 구에서 압력 변화는 크게 보이지 않았으며 $(\mathrm{p}>0.05)$ 대기 압력인 $1.002 \mathrm{~atm}$ 과 같은 수치를 나타내었다. 이 결과, 일본 과 중국에서 생산된 김치와 한국에서 생산된 김치의 파우치 내부 압력 차이가 없음을 알 수 있다. $4{ }^{\circ} \mathrm{C}$ 에 저장된 김치 파우치 내부의 가스 조성 변화 결과는 Fig. 4 와 같다. 파우치 내부의 대기 조성은 저장 0 일차와 63 일차에 측정하였다. 저장 0 일차의 가스 조성은 모든 처리구가 대기의 가스 조성 과 같은 값인 $\mathrm{O}_{2}=20.90 \%, \mathrm{CO}_{2}=0.30 \%, \mathrm{~N}_{2}=78.80 \%$ 의 값과 같았다. 그러나 저장 63 일차의 가스 조성은 각 샘플마다 큰 차이를 나타내었다 $(\mathrm{p}<0.05)$. 대부분의 처리구가 $\mathrm{CO}_{2}>$ $\mathrm{N}_{2}>\mathrm{O}_{2}$ 순의 가스 조성을 가지지만 일본 김치의 경우는
$\mathrm{N}_{2}>\mathrm{O}_{2}>\mathrm{CO}_{2}$ 순의 가스 조성을 보여 주었다. 김치 발효로부 터의 $\mathrm{CO}_{2}$ 발생은 상당히 많은 부분이 이질젖산발효균인 Leuconostoc mesenteroides로부터 기인하는 것으로 알려졌 으며 이는 김치의 탄산미와 같은 풍미를 주는 역할을 하지 만, 포장의 팽창이나 압력 발생을 유발하기도 한다. 김치는 숙성 초기에 Leuconostoc spp. 과 Lactobacillus spp. 등의 이 질 발효 젖산균이 증식하면서 발효 부산물인 $\mathrm{CO}_{2}$ 가스를 생성하는데, 이는 포장 내부의 $\mathrm{O}_{2}$ 농도는 감소시키고 $\mathrm{CO}_{2}$ 농도는 증가하게 한다(27-29). 김치의 저장 중 미생물 특성 과 $\mathrm{pH}$, 산도 결과를 보면 일본 김치는 중국 김치 한국 김치 에 비해 발효가 일어나지 않는 것을 알 수 있다. 미생물이 생성되는 양이 적기 때문에 다른 처리구에 비해 $\mathrm{CO}_{2}$ 의 발생 량도 적다는 결과를 얻을 수 있었다.

\section{한국, 일본, 중국 제조 김치 김치의 관능평가 결과}

Table 3 와 Table 4 는 한국, 일본, 중국 제조 김치의 관능평 가 결과를, Fig. 5는 전체적인 기호도를 보여준다. 관능평가 결과를 보면 저장 온도에 따른 유의적인 차이는 없었고 $(\mathrm{p}>0.05)$ 국가 간 관능적 차이는 있었다 $(\mathrm{p}<0.05)$. 김치의

Table 3. Sensory evaluations of the kimchi stored at $15^{\circ} \mathrm{C}$

\begin{tabular}{|c|c|c|c|c|c|c|c|c|}
\hline categories & Period (day) & Japan & China & Korea 1 & Korea 2 & Korea 3 & Korea 4 & Korea 5 \\
\hline \multirow{3}{*}{$\begin{array}{l}\text { Color } \\
\text { (redness) }\end{array}$} & 0 & $4.80 \pm 1.93^{1 \mathrm{~B} 2 \mathrm{a}) \mathrm{a} 3}$ & $6.30 \pm 1.16^{\mathrm{Aa}}$ & $3.70 \pm 0.82^{\mathrm{Cb}}$ & $3.90 \pm 1.10^{\mathrm{BCa}}$ & $4.00 \pm 1.41^{\mathrm{BCa}}$ & $3.50 \pm 0.71^{\mathrm{Ca}}$ & $6.40 \pm 1.65^{\mathrm{Aa}}$ \\
\hline & 5 & $5.10 \pm 0.99^{\mathrm{Aa}}$ & $5.60 \pm 1.71^{\mathrm{Aab}}$ & $5.00 \pm 1.05^{\mathrm{Aa}}$ & $5.10 \pm 1.60^{\mathrm{ABa}}$ & $3.10 \pm 0.99^{\mathrm{cb}}$ & $3.90 \pm 0.74^{\mathrm{BCa}}$ & $5.00 \pm 1.76^{\mathrm{ABb}}$ \\
\hline & 20 & $5.70 \pm 1.64^{\mathrm{ABa}}$ & $4.80 \pm 1.69^{\mathrm{BCb}}$ & $5.20 \pm 1.32^{\mathrm{ABa}}$ & $5.00 \pm 1.41^{\mathrm{ABa}}$ & $2.90 \pm 1.20^{\mathrm{Db}}$ & $3.50 \pm 1.78^{\mathrm{CDa}}$ & $6.20 \pm 1.93^{\mathrm{Aab}}$ \\
\hline \multirow{3}{*}{ Sourness } & 0 & $3.90 \pm 1.85^{\mathrm{Da}}$ & $06.20 \pm 1.48^{\mathrm{ABCa}}$ & $4.50 \pm 1.96^{\mathrm{BCb}}$ & $4.30 \pm 1.89^{\mathrm{Db}}$ & $4.80 \pm 1.87^{\mathrm{BCDb}}$ & $6.30 \pm 1.16^{\mathrm{ABb}}$ & $6.50 \pm 1.90^{\mathrm{Aa}}$ \\
\hline & 5 & $4.00 \pm 1.70^{\mathrm{Ba}}$ & $6.70 \pm 1.64^{\mathrm{Aa}}$ & $6.20 \pm 1.48^{\mathrm{Aa}}$ & $6.90 \pm 1.20^{\mathrm{Aa}}$ & $6.40 \pm 1.43^{\mathrm{Aa}}$ & $7.00 \pm 1.49^{\mathrm{Aa}}$ & $6.70 \pm 1.49^{\mathrm{Aa}}$ \\
\hline & 20 & $3.90 \pm 1.79^{\mathrm{Ba}}$ & $6.70 \pm 1.49^{\mathrm{Aa}}$ & $7.70 \pm 1.25^{\mathrm{Aa}}$ & $7.40 \pm 1.51^{\mathrm{Aa}}$ & $7.50 \pm 1.08^{\mathrm{Aa}}$ & $8.20 \pm 1.14^{\mathrm{Aa}}$ & $7.60 \pm 1.84^{\mathrm{Aa}}$ \\
\hline \multirow{3}{*}{ Sweetness } & 0 & $6.20 \pm 1.87^{\mathrm{Aa}}$ & $5.00 \pm 1.76^{\mathrm{ABa}}$ & $5.30 \pm 1.77^{\mathrm{ABa}}$ & $5.60 \pm 1.71^{\mathrm{ABa}}$ & $4.50 \pm 1.65^{\mathrm{ABa}}$ & $5.00 \pm 1.05^{\mathrm{ABa}}$ & $3.90 \pm 1.10^{\mathrm{Ba}}$ \\
\hline & 5 & $6.60 \pm 1.51^{\mathrm{Aa}}$ & $5.00 \pm 1.76^{\mathrm{Ba}}$ & $4.50 \pm 1.08^{\mathrm{Ba}}$ & $4.80 \pm 1.03^{\mathrm{Ba}}$ & $4.60 \pm 1.17^{\mathrm{Ba}}$ & $4.80 \pm 1.55^{\mathrm{Ba}}$ & $4.70 \pm 1.25^{\mathrm{Ba}}$ \\
\hline & 20 & $7.40 \pm 0.84^{\mathrm{Aa}}$ & $5.60 \pm 1.35^{\mathrm{Ba}}$ & $4.60 \pm 1.51^{\mathrm{Ba}}$ & $4.80 \pm 1.40^{\mathrm{Ba}}$ & $5.20 \pm 1.40^{\mathrm{Ba}}$ & $4.60 \pm 1.43^{\mathrm{Ba}}$ & $4.70 \pm 2.21^{\mathrm{Ba}}$ \\
\hline \multirow{3}{*}{ Hot taste } & 0 & $4.00 \pm 1.70^{\mathrm{Ca}}$ & $5.90 \pm 1.85^{\mathrm{Aa}}$ & $4.30 \pm 1.95^{\mathrm{BCa}}$ & $4.60 \pm 1.07^{\mathrm{BCa}}$ & $5.30 \pm 1.42^{\mathrm{ABa}}$ & $5.60 \pm 1.17^{\mathrm{ABab}}$ & $4.60 \pm 1.43^{\mathrm{BCa}}$ \\
\hline & 5 & $3.70 \pm 0.82^{\mathrm{Ba}}$ & $5.20 \pm 1.40^{\mathrm{Aa}}$ & $5.00 \pm 1.25^{\mathrm{Aa}}$ & $4.90 \pm 1.20^{\mathrm{ABa}}$ & $5.60 \pm 1.17^{\mathrm{Aa}}$ & $4.60 \pm 1.07^{\mathrm{ABb}}$ & $5.00 \pm 1.49^{\mathrm{Aa}}$ \\
\hline & 20 & $3.80 \pm 1.23^{\mathrm{Ca}}$ & $5.90 \pm 1.52^{\mathrm{ABa}}$ & $5.20 \pm 1.23^{\mathrm{Ba}}$ & $4.90 \pm 1.45^{\mathrm{Ba}}$ & $5.80 \pm 1.75^{\mathrm{ABa}}$ & $6.40 \pm 1.17^{\mathrm{Aa}}$ & $5.40 \pm 1.58^{\mathrm{ABa}}$ \\
\hline \multirow{3}{*}{ Odour } & 0 & $6.60 \pm 1.17^{\mathrm{Aa}}$ & $4.30 \pm 2.26^{\mathrm{Bb}}$ & $5.00 \pm 2.26^{\mathrm{ABa}}$ & $4.30 \pm 1.42^{\mathrm{Ba}}$ & $4.50 \pm 2.12^{\mathrm{Ba}}$ & $4.70 \pm 1.57^{\mathrm{Bb}}$ & $5.20 \pm 2.04^{\mathrm{Ba}}$ \\
\hline & 5 & $7.50 \pm 1.18^{\mathrm{Aa}}$ & $6.40 \pm 2.17^{\mathrm{ABab}}$ & $6.40 \pm 1.84^{\mathrm{ABa}}$ & $5.20 \pm 1.48^{\mathrm{Ba}}$ & $5.90 \pm 2.02^{\mathrm{Ba}}$ & $6.30 \pm 1.42^{\mathrm{ABa}}$ & $6.00 \pm 2.05^{\mathrm{ABa}}$ \\
\hline & 20 & $7.50 \pm 1.58^{\mathrm{Aa}}$ & $6.40 \pm 1.90^{\mathrm{Aa}}$ & $5.60 \pm 2.76^{\mathrm{ABa}}$ & $4.30 \pm 1.95^{\mathrm{Ba}}$ & $6.40 \pm 2.50^{\mathrm{ABa}}$ & $5.70 \pm 2.45^{\mathrm{ABab}}$ & $6.70 \pm 2.54^{\mathrm{Aa}}$ \\
\hline \multirow{3}{*}{ Crunch } & 0 & $4.80 \pm 2.10^{\mathrm{Ca}}$ & $5.20 \pm 1.14^{\mathrm{BCa}}$ & $5.40 \pm 1.58^{\mathrm{BCa}}$ & $5.60 \pm 1.35^{\mathrm{ABCa}}$ & $5.90 \pm 1.60^{\mathrm{ABa}}$ & $5.70 \pm 1.16^{\mathrm{BCa}}$ & $6.70 \pm 0.82^{\mathrm{Aa}}$ \\
\hline & 5 & $4.10 \pm 1.91^{\mathrm{Ba}}$ & $5.70 \pm 1.64^{\mathrm{Aa}}$ & $5.20 \pm 0.92^{\mathrm{ABab}}$ & $5.30 \pm 0.82^{\mathrm{ABa}}$ & $5.30 \pm 1.34^{\mathrm{ABa}}$ & $5.90 \pm 0.88^{\mathrm{Aa}}$ & $5.90 \pm 0.99^{\mathrm{Aab}}$ \\
\hline & 20 & $3.80 \pm 1.62^{\mathrm{Ba}}$ & $4.10 \pm 1.60^{\mathrm{Bb}}$ & $4.20 \pm 1.23^{\mathrm{ABb}}$ & $5.10 \pm 1.73^{\mathrm{ABa}}$ & $4.80 \pm 1.23^{\mathrm{ABa}}$ & $5.20 \pm 1.55^{\mathrm{Aa}}$ & $4.80 \pm 1.48^{\mathrm{ABb}}$ \\
\hline \multirow{3}{*}{$\begin{array}{c}\text { Overall } \\
\text { acceptance }\end{array}$} & 0 & $3.00 \pm 1.41^{\mathrm{Ba}}$ & $3.90 \pm 2.02^{\mathrm{ABa}}$ & $4.30 \pm 1.83^{\mathrm{ABa}}$ & $4.60 \pm 1.07^{\mathrm{Aa}}$ & $4.80 \pm 1.87^{\mathrm{Aa}}$ & $4.70 \pm 1.42^{\mathrm{Aa}}$ & $3.90 \pm 1.73^{\mathrm{ABa}}$ \\
\hline & 5 & $2.20 \pm 0.79^{\mathrm{Bab}}$ & $4.00 \pm 1.94^{\mathrm{Aa}}$ & $3.90 \pm 1.66^{\mathrm{Aa}}$ & $4.60 \pm 0.84^{\mathrm{Aa}}$ & $4.50 \pm 1.78^{\mathrm{Aa}}$ & $3.90 \pm 1.20^{\mathrm{Aa}}$ & $3.90 \pm 1.66^{\mathrm{Aa}}$ \\
\hline & 20 & $1.80 \pm 0.92^{\mathrm{Cb}}$ & $3.10 \pm 0.99^{\mathrm{BCa}}$ & $3.10 \pm 0.99^{\mathrm{Ba}}$ & $5.00 \pm 1.76^{\mathrm{Aa}}$ & $3.00 \pm 1.63^{\mathrm{Ba}}$ & $3.70 \pm 1.89^{\mathrm{Ba}}$ & $2.40 \pm 1.71^{\mathrm{BCa}}$ \\
\hline
\end{tabular}

${ }^{1)}$ All values are mean $\pm \mathrm{SD}(\mathrm{n}=15)$.

2)A-G Means sharing different letters in the same row are significantly different by Duncan's multiple range test $(\mathrm{p}<0.05)$.

${ }^{3) a-1}$ Means sharing different letters in the same column are significantly different by Duncan's multiple range test $(\mathrm{p}<0.05)$. 
Table 4. Sensory evaluations of kimchi stored at $4{ }^{\circ} \mathrm{C}$

\begin{tabular}{|c|c|c|c|c|c|c|c|c|}
\hline categories & Period (day) & Japan & China & Korea 1 & Korea 2 & Korea 3 & Korea 4 & Korea 5 \\
\hline \multirow{3}{*}{$\begin{array}{c}\text { Color } \\
\text { (redness) }\end{array}$} & 0 & $4.80 \pm 1.93^{1 /(1) 2)(3)}$ & $6.30 \pm 1.16^{\mathrm{Aa}}$ & $3.70 \pm 0.82^{\mathrm{Ca}}$ & $3.90 \pm 1.10^{\mathrm{BCb}}$ & $4.00 \pm 1.41^{\mathrm{BCb}}$ & $3.50 \pm 0.71^{\mathrm{Ca}}$ & $6.40 \pm 1.65^{\mathrm{Aa}}$ \\
\hline & 21 & $4.40 \pm 0.84^{\mathrm{BCa}}$ & $4.50 \pm 0.97^{\mathrm{BCb}}$ & $4.20 \pm 1.03^{\mathrm{BCa}}$ & $5.70 \pm 0.95^{\mathrm{ABa}}$ & $4.10 \pm 1.28^{\mathrm{BCa}}$ & $3.60 \pm 1.07^{\mathrm{Ca}}$ & $6.00 \pm 0.82^{\mathrm{Aa}}$ \\
\hline & 49 & $4.70 \pm 1.42^{\mathrm{ABa}}$ & $5.80 \pm 1.48^{\mathrm{Aab}}$ & $4.20 \pm 1.55^{\mathrm{Ba}}$ & $4.20 \pm 1.03^{\mathrm{Bb}}$ & $4.00 \pm 1.15^{\mathrm{Bb}}$ & $3.80 \pm 1.40^{\mathrm{Ba}}$ & $2.95 \pm 1.79^{\mathrm{Bb}}$ \\
\hline \multirow{3}{*}{ Sourness } & 0 & $3.90 \pm 1.85^{\mathrm{Da}}$ & $6.20 \pm 1.48^{\mathrm{ABCa}}$ & $4.50 \pm 1.96^{\mathrm{BCb}}$ & $4.30 \pm 1.89^{\mathrm{Db}}$ & $4.80 \pm 1.87^{\mathrm{BCDb}}$ & $6.30 \pm 1.16^{\mathrm{ABa}}$ & $6.50 \pm 1.90^{\mathrm{Aa}}$ \\
\hline & 21 & $4.70 \pm 1.70^{\mathrm{Ba}}$ & $5.70 \pm 1.42^{\mathrm{ABa}}$ & $6.70 \pm 1.06^{\mathrm{Aa}}$ & $6.30 \pm 1.34^{\mathrm{Aa}}$ & $6.20 \pm 1.20^{\mathrm{Aa}}$ & $6.90 \pm 0.99^{\mathrm{Aa}}$ & $6.90 \pm 1.37^{\mathrm{Aa}}$ \\
\hline & 49 & $4.30 \pm 1.83^{\mathrm{Aa}}$ & $6.50 \pm 2.12^{\mathrm{Ba}}$ & $6.40 \pm 1.90^{\mathrm{Ba}}$ & $7.20 \pm 1.23^{\mathrm{Ba}}$ & $6.40 \pm 1.51^{\mathrm{Ba}}$ & $7.10 \pm 1.45^{\mathrm{Ba}}$ & $3.94 \pm 2.46^{\mathrm{Ba}}$ \\
\hline \multirow{3}{*}{ Sweetness } & 0 & $6.20 \pm 1.87^{\mathrm{Aa}}$ & $5.00 \pm 1.76^{\mathrm{ABa}}$ & $5.30 \pm 1.77^{\mathrm{ABa}}$ & $5.60 \pm 1.71^{\mathrm{ABa}}$ & $4.50 \pm 1.65^{\mathrm{ABa}}$ & $5.00 \pm 1.05^{\mathrm{ABa}}$ & $3.90 \pm 1.10^{\mathrm{Ba}}$ \\
\hline & 21 & $6.30 \pm 1.42^{\mathrm{Aa}}$ & $5.40 \pm 2.07^{\mathrm{ABa}}$ & $4.00 \pm 1.56^{\mathrm{Cb}}$ & $4.30 \pm 1.70^{\mathrm{Cab}}$ & $4.50 \pm 1.51^{\mathrm{BCa}}$ & $4.70 \pm 1.06^{\mathrm{BCa}}$ & $4.50 \pm 1.78^{\mathrm{BCa}}$ \\
\hline & 49 & $6.70 \pm 2.06^{\mathrm{Aa}}$ & $5.20 \pm 1.62^{\mathrm{Ba}}$ & $3.90 \pm 1.85^{\mathrm{Bb}}$ & $4.20 \pm 1.40^{\mathrm{Bb}}$ & $4.50 \pm 1.27^{\mathrm{Ba}}$ & $4.60 \pm 1.26^{\mathrm{Ba}}$ & $3.27 \pm 1.88^{\mathrm{Ba}}$ \\
\hline \multirow{3}{*}{ Hot taste } & 0 & $4.00 \pm 1.70^{\mathrm{Ca}}$ & $5.90 \pm 1.85^{\mathrm{Aa}}$ & $4.30 \pm 1.95^{\mathrm{BCa}}$ & $4.60 \pm 1.07^{\mathrm{BCa}}$ & $5.30 \pm 1.42^{\mathrm{ABa}}$ & $5.60 \pm 1.17^{\mathrm{ABa}}$ & $4.60 \pm 1.43^{\mathrm{BCa}}$ \\
\hline & 21 & $4.10 \pm 0.99^{\mathrm{Ca}}$ & $5.90 \pm 1.37^{\mathrm{Aa}}$ & $4.80 \pm 1.40^{\mathrm{ABCa}}$ & $5.00 \pm 1.33^{\mathrm{ABCa}}$ & $5.10 \pm 1.29^{\mathrm{ABCa}}$ & $5.60 \pm 1.26^{\mathrm{ABa}}$ & $4.60 \pm 1.26^{\mathrm{BCa}}$ \\
\hline & 49 & $4.20 \pm 1.48^{\mathrm{Ba}}$ & $5.80 \pm 1.69^{\mathrm{Aa}}$ & $5.10 \pm 1.45^{\mathrm{ABa}}$ & $5.50 \pm 1.27^{\mathrm{ABa}}$ & $5.60 \pm 1.07^{\mathrm{Aa}}$ & $6.00 \pm 1.56^{\mathrm{Aa}}$ & $3.32 \pm 2.08^{\mathrm{ABa}}$ \\
\hline \multirow{3}{*}{ Odour } & 0 & $6.60 \pm 1.17^{\mathrm{Aa}}$ & $4.30 \pm 2.26^{\mathrm{Ba}}$ & $5.00 \pm 2.26^{\mathrm{ABa}}$ & $4.30 \pm 1.42^{\mathrm{Bb}}$ & $4.50 \pm 2.12^{\mathrm{Ba}}$ & $4.70 \pm 1.57^{\mathrm{Ba}}$ & $5.20 \pm 2.04^{\mathrm{Ba}}$ \\
\hline & 21 & $6.60 \pm 2.37^{\mathrm{Aa}}$ & $5.70 \pm 1.89^{\mathrm{ABa}}$ & $6.20 \pm 2.25^{\mathrm{ABa}}$ & $5.20 \pm 1.62^{\mathrm{ABab}}$ & $4.50 \pm 1.96^{\mathrm{Ba}}$ & $4.70 \pm 2.16^{\mathrm{ABa}}$ & $5.50 \pm 2.01^{\mathrm{ABa}}$ \\
\hline & 49 & $7.50 \pm 2.01^{\mathrm{Aa}}$ & $6.40 \pm 2.22^{\mathrm{ABa}}$ & $7.00 \pm 1.89^{\mathrm{Aa}}$ & $6.10 \pm 1.91^{\mathrm{ABa}}$ & $5.90 \pm 2.13^{\mathrm{ABa}}$ & $5.00 \pm 2.11^{\mathrm{Ba}}$ & $4.31 \pm 2.44^{\mathrm{Aa}}$ \\
\hline \multirow{3}{*}{ Crunch } & 0 & $4.80 \pm 2.10^{\mathrm{Ca}}$ & $5.20 \pm 1.14^{\mathrm{BCa}}$ & $5.40 \pm 1.58^{\mathrm{BCa}}$ & $5.60 \pm 1.35^{\mathrm{ABCa}}$ & $5.90 \pm 1.60^{\mathrm{ABa}}$ & $5.70 \pm 1.16^{\mathrm{BCa}}$ & $6.70 \pm 0.82^{\mathrm{Aa}}$ \\
\hline & 21 & $4.10 \pm 1.60^{\mathrm{Ba}}$ & $4.60 \pm 1.51^{\mathrm{ABa}}$ & $5.30 \pm 1.16^{\mathrm{Aa}}$ & $5.90 \pm 0.99^{\mathrm{Aa}}$ & $5.60 \pm 1.51^{\mathrm{Aa}}$ & $5.20 \pm 1.40^{\mathrm{ABa}}$ & $5.20 \pm 1.23^{\mathrm{ABa}}$ \\
\hline & 49 & $4.30 \pm 1.34^{\mathrm{BCa}}$ & $3.10 \pm 1.79^{\mathrm{Cb}}$ & $5.00 \pm 1.33^{\mathrm{ABa}}$ & $5.40 \pm 2.12^{\mathrm{ABa}}$ & $5.30 \pm 1.06^{\mathrm{ABa}}$ & $6.00 \pm 0.94^{\mathrm{Aa}}$ & $3.07 \pm 1.77^{\mathrm{ABb}}$ \\
\hline \multirow{3}{*}{$\begin{array}{c}\text { Overall } \\
\text { acceptance }\end{array}$} & 0 & $3.00 \pm 1.41^{\mathrm{Ba}}$ & $3.90 \pm 2.02^{\mathrm{ABa}}$ & $4.30 \pm 1.83^{\mathrm{ABa}}$ & $4.60 \pm 1.07^{\mathrm{Aa}}$ & $4.80 \pm 1.87^{\mathrm{Aa}}$ & $4.70 \pm 1.42^{\mathrm{Aa}}$ & $3.90 \pm 1.73^{\mathrm{ABa}}$ \\
\hline & 21 & $3.10 \pm 1.66^{\mathrm{Ba}}$ & $3.60 \pm 1.07^{\mathrm{ABa}}$ & $3.70 \pm 1.83^{\mathrm{ABa}}$ & $4.50 \pm 1.27^{\mathrm{Aa}}$ & $4.50 \pm 1.35^{\mathrm{Aa}}$ & $4.80 \pm 2.15^{\mathrm{Aa}}$ & $3.90 \pm 1.97^{\mathrm{ABa}}$ \\
\hline & 49 & $2.50 \pm 1.51^{\mathrm{Ca}}$ & $3.00 \pm 1.25^{\mathrm{BCa}}$ & $3.10 \pm 1.29^{\mathrm{BCa}}$ & $3.90 \pm 0.99^{\mathrm{ABCa}}$ & $4.30 \pm 1.49^{\mathrm{ABa}}$ & $4.60 \pm 1.90^{\mathrm{Aa}}$ & $2.33 \pm 1.19^{\mathrm{Ca}}$ \\
\hline
\end{tabular}

${ }^{1)}$ All values are mean $\pm \mathrm{SD}(\mathrm{n}=15)$.

2)A-G Means sharing different letters in the same row are significantly different by Duncan's multiple range test $(p<0.05)$.

${ }^{3) a-5}$ Means sharing different letters in the same column are significantly different by Duncan's multiple range test $(p<0.05)$.

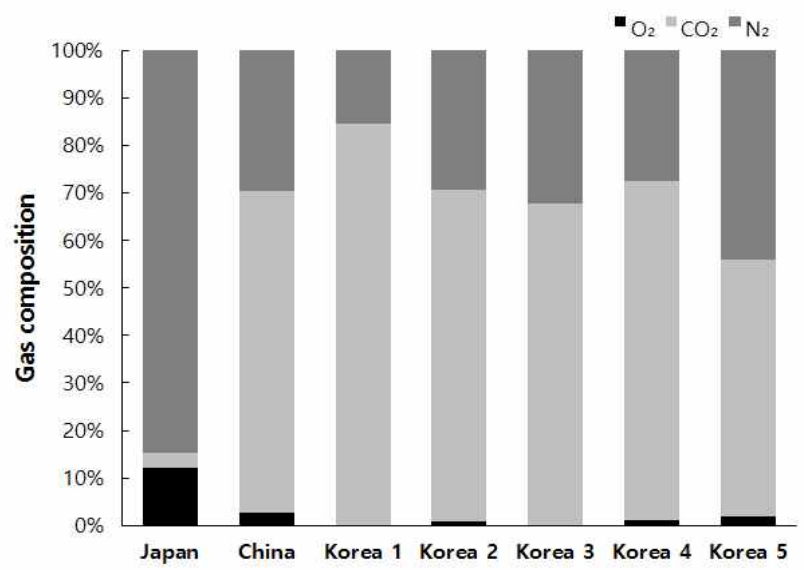

Fig. 4. The head space atmosphere compositions in the pouches during storage at $4^{\circ} \mathrm{C}$ in the 63 days.

관능적 특징을 결정짓는 요소는 미생물, 산도, 염도, $\mathrm{pH}$ 등이 있다. 발효 중 여러 유기산이 생성되어 김치에 산미를 부여함과 동시에 김치의 각종 부재료들로부터 용출된 여타 의 맛 성분들이 조화를 이루며 김치 고유의 맛을 지니게
된다(26). 관능평가 결과, 외관을 평가하는 김치의 색은 저 장기간이 길어질수록 낮은 점수를 얻었다. 즉, 양념은 배추 에 스며들고 김치의 색이 어두워지는 현상이 발생하였다. 잘 익은 냄새는 김치가 발효되면서 나타나는 신냄새로 중국 김치에서 가장 높은 점수를 나타내었으며, 이취는 $4^{\circ} \mathrm{C}$ 에 저장된 김치보다 $15^{\circ} \mathrm{C}$ 에 저장된 김치가 더 높은 것으로 보아 높은 온도인 $15^{\circ} \mathrm{C}$ 에서 저장된 김치의 산패취가 더 강했음을 알 수 있다. 전반적인 선호도는 한국 김치, 중국 김치, 일본 김치 순이었다. 일본 김치의 경우에는 중국 김치, 한국 김치에 비해 신맛, 매운맛은 약하고 단맛은 강하게 나타났다. 중국 김치는 전반적으로 한국 김치보다 젓갈 냄 새가 약하고 매운 맛이 다소 강한 편이다(17). 조직감은 한국 김치가 일본 김치와 중국 김치보다 더 아삭하고 덜 무른 결과 값을 나타내었는데, 이는 재배되는 배추와 절임 방법의 영향을 많이 받는다고 알려져 있다. 실제로, 일본에 서 생산되는 배추의 경우 한국에서 생산되는 배추보다 수분 이 많고 조직이 약하여 씹는 맛이 적다는 연구 결과가 있다 (18). 반면에, 한국산 배추는 일본산 배추보다 수분 함량이 적고 조직감이 좋아 김치 제조시 유산균은 높게 나타나고 
신맛과 물러짐이 더디게 나타난다는 연구 결과가 발표된 바 있다(18). 결과적으로 한국김치가 관능평가 부분에서 일본, 중국 김치보다 우수하였으며 특히, 한국김치 $2,3,4$ 의 기호도가 높게 나타났다.

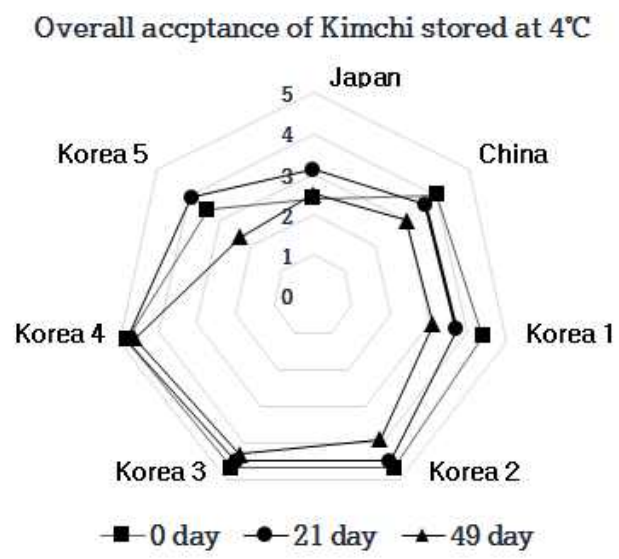

Overall accptance of Kimchi stored at $15^{\circ} \mathrm{C}$

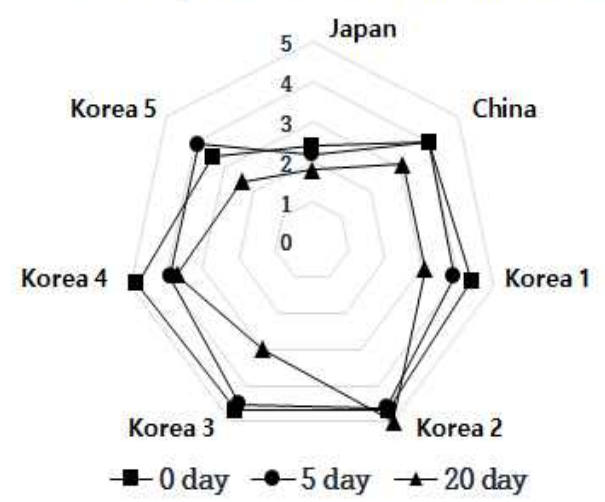

Fig. 5. The overall acceptance of kimchi stored at $4{ }^{\circ} \mathrm{C}$ and $15^{\circ} \mathrm{C}$. Values represent the mean $\pm \mathrm{SD}(\mathrm{n}=3)$.

\section{요 약}

본 연구는 한국김치의 수출 촉진을 위한 품질 차별화를 목적으로 진행되었으며 이를 위해서 현지 수출 시장에서 제조된 김치와 한국에서 제조된 김치의 품질을 비교 분석하 였다. 한·중·일 삼국의 김치는 이화학적 특성 $(\mathrm{pH}$, 산도, 염 도), 미생물적 특성, 관능적 특성이 각각 다르게 나타났다. 이러한 결과는 각국의 김치 재료 및 제조 방법 등이 김치의 이화학적, 미생물학적, 관능적 품질에 영향을 준 것으로 보인다. 특히, 저장 기간 동안 한국김치는 Lactic acid bacteria, Lactobacillus spp., Leuconostoc spp.와 전체적인 관능 기호도에서 높은 값을 나타냈다. 본 연구는 한국 김치 품질의 우수성을 증명하고 타 국가에서의 김치 소비 특성을 예측하는데 도움이 될 것으로 기대된다.

\section{감사의 글}

본 연구는 세계김치연구소 기관고유사업(KE1602-3-1) 및 (사)광주명품김치사업단의 연구비 지원에 의해 수행되 었으며, 이에 감사드립니다.

\section{References}

1. Kim HR, Kim MR (2010) Effects of traditional salt on the quality characteristics and growth of microorganisms from kimchi. Korean J Food Culture, 25, 61-69

2. Gwangju City (2008) Korean taste, gwangju kimchi Gamchilbaegi. Design ssing Publisher, Gwangju, Korea, p 26-28

3. Kim JH, Park JG, Lee JW, Kim WG, Chung YJ, Byun MW (2008) The combined effects of $\mathrm{N}_{2}$-packaging, heating and gamma irradiation on the shelf-stability of Kimchi, Korean fermented vegetable. Food control, 19, 56-61

4. Park KY (1995) The nutritional evaluation, and anti mutagenic and anticancer effects of kimchi. J Korean Soc Food Sci Nutr, 24, 169-182

5. Lee HJ (2000) A study on commercial kimchi consumption of housewives is Seoul and Chungbuk area. Korean J Food Nutr, 13, 221-225

6. Park WP, Park KD, Cheong YJ, Lee IS (2002) Effect of calcium powder addition on the quality characteristics of kimchi. J Korean Soc Food Sci Nutr, 31, 428-432

7. Food Journal (2010) Food distribution yearbook. Food Journal editorial department, Seoul, Korea, p 351-353

8. Health (2006) The world's 5 healthiest food. Time inc, NY, USA, March 2006, 106-121

9. Han JS, Cho YS, Lee SJ (2003) A comparision on the quality characteristics of Korean and Japanese Commercial baechu kimchi. J Korean Home Econ Assoc, $41,85-92$

10. World Institute of Kimchi (2013) kimchi export guide book (Japan). Korean Studies Information, Gwangju, Korea, p 48-56

11. Ku KH, Cho JS, Park WS, Nam YJ (1999) Effects of sorbitol and sugar sources on the fermentation and sensory properties of Baechu kimchi. Korean J Food Sci Technol, 31, 794-801

12. Lee JH (2008) Kimchi from Korean traditional food to global food. Food Science and Industry, 41, 23-27

13. Hwang KS (2005) Current status and further development 
perspectives of exported Korean kimchi into Japan. Food Preserv Process Ind, 4, 46-56

14. Lee EJ, Park SE, Choi HS, Han GJ, Kang SA, Park KY (2010) Quality characteristics of kimchi fermented in permeability-controlled polyethylene containers. J Korean Food Preserv, 17, 793-799

15. Chang JY, Choi YR, Chang HC (2011) Change in the microbial profiles of commercial kimchi during fermentation. Korean J Food Preserv, 18, 786-794

16. Kim HY, Kil JH, Park KY (2013) Comparing the properties and functionality of kimchi made with Korean or Japanese baechu cabbage and recipes. J Korean Soc Food Sci Nutr, 42, 520-526

17. Cho SK, Moon JS, Kim YJ, Kim JE, Choi HY, Ahn JE, Otgonbayar GE, Eom HJ, Kim TJ, Kim YM, Kim HR, Han NS (2012) Comparison of chemical and microbiological characteristics of commercial kimchi products in Korea and Japan. Korean J Food Sci Technol, 44, 155-161

18. Nam KO (2011) A Study on the export marketing strategy for Korean kimchi industry in Japan market. MS Thesis, Chungwoon University, Korea, p 35-36

19. Cho HJ, Cho JA (1998) The study on the kimchi in Chulra-Do. The natural science research institute myongji university, Korea, 17, 166-172

20. Han KI, Kim MJ, Kwon HJ, Kim YH, Kim WJ, Han MD (2013) The Effect of container types on the growth of bacteria during kimchi fermentation. Korean J Food Nutr, 26, 249-257

21. Lim JH, Park SS, Jeong JW, Park KJ, Seo KH, Sung JM (2013) Quality characteristics of kimchi fermented with abalone or sea tangle extracts. J Korean Soc Food Sci Nutr, 42, 450-456
22. You BR, Kim EG, Jang JY, Choi HJ, Kim HJ (2013) Quality characteristics of kimchi with allium hookeri root powder added. J Korean Food Preserv, 20, 863-870

23. Salminen S, Wright AV (2004) Lactic acid bacteria : Microbiological and functional aspects. 3rd ed, CRC Press, Boca Raton, FL, USA, p 380-405

24. Shin DH, Kim MS, Han JS, Lim DK, Park WS (1996) Changes of chemical composition and microflora in commercial kimchi. Korean J Food Sci Technol, 28, 137-145

25. Shin DH (1994) Physicochemical and microbial properties of market kimchi during fermentation in different containers. Korean J Food Sci Technol, 226-245

26. Maurice ES, Shike M, Ross AC, Caballero B, Cousins RJ (2005) Nutrition and diet in hypertension. In: Modern nutrition in health and disease. 10th ed. Lippincott Williams \& Wikins, Philadelphia, PA, USA, p 1095-1107

27. Choi HS (2004) Food Science and fermentation of kimchi. Hyo-il publishing company, Seoul, Korea, p 193-220

28. Mheen TI, Kwon TW (1984) Effect of temperature and salt concentration on kimchi fermentation. Korean J Food Sci Technol, 16, 443-450

29. Lee DS, Paik HD (1997) Use of a pinhole to develop an active packaging system for kimchi, a Korean fermented vegetable. Packag Technol Sci, 10, 33-43

30. Kim DK, Kim SY, Lee JK, Noh BS (2000) Effects of xylose and xylitol on the organic acid fermentation of kimchi. Korean J Food Sci Technol, 32, 889-895 